\title{
The Practice of Palliative Care amongst Nurses in Selected Hospitals in Eastern Nigeria
}

\author{
Emmanuela Chinenye Anyanwu ${ }^{1}$, Clara Agbedia ${ }^{2}$ \\ ${ }^{1}$ School of Nursing, Alex Ekwueme Federal University Teaching Hospital, Abakaliki, Nigeria \\ ${ }^{2}$ Department of Nursing, Delta State University, Abraka, Delta State, Nigeria \\ Email: oniovo4life@gmail.com
}

How to cite this paper: Anyanwu, E.C. and Agbedia, C. (2020) The Practice of Palliative Care amongst Nurses in Selected Hospitals in Eastern Nigeria. Open Journal of Nursing, 10, 617-635. https://doi.org/10.4236/ojn.2020.106043

Received: March 26, 2020

Accepted: June 7, 2020

Published: June 10, 2020

Copyright () 2020 by author(s) and Scientific Research Publishing Inc. This work is licensed under the Creative Commons Attribution International License (CC BY 4.0).

http://creativecommons.org/licenses/by/4.0/

\section{(c) (i) Open Access}

\begin{abstract}
In recent times, palliative care nursing has caught the attention of nurse researchers in Africa as more individuals are being diagnosed with chronic diseases of the aged like cancer, cardiac and cerebrovascular conditions. This study examined the influence of knowledge and attitude on the practice of palliative care among practicing nurses in eastern part of Nigeria. A descriptive cross-sectional research design was used for the study. The population of the study is all registered, licensed and practicing nurses working in the named public and private hospitals where palliative care is supposedly well established. Proportionate sampling technique was used to select 289 respondents. Three commercial instruments that were modified were used for data collection. Level of significance was set at $5 \%$. The study was conducted from October 2018 to June 2019. Results revealed that $52.7 \%$ of the respondents had satisfactory practice of palliative care, $73.7 \%$ of the respondents had adequate knowledge of palliative care (mean 2.64 (1.06) and 77.5\% of the respondents had positive attitude towards palliative care (Mean 2.81 (1.14)). There was also a significant weak positive association between nurses' educational level and their knowledge of palliative care with an effect size of $21.9 \%$ $(P=0.003)$. There was also a significant association between nurses' years of experience and their attitude to palliative care with an effect size of $35.6 \%$ ( $P$ $<0.001)$. There was no significant association between type of hospital facility nurses work in and their practice of palliative care $(P=0.343)$. Recommendations were made on how to improve the practice of palliative care among professional nurses.
\end{abstract}

\section{Keywords}

Practice of Palliative Care, Knowledge, Attitude, Years of Experience, Type of Hospital Facility 


\section{Introduction}

Throughout the past decade, the world has experienced growing health enhancing technology that has had a significant influence on medical science and practice. The average life expectancy at birth worldwide had increased from 58.7 years in 2009 to 71.4 years in 2015 [1]. With this increasing global life expectancy more individuals are being diagnosed with chronic diseases of the aged like cancer, cardiac and cerebrovascular conditions. The increased global life expectancy implies that individuals with chronic and debilitating illnesses must be provided comfort to maintain the highest possible Quality of Life (Qol) for as long as life remains. This is palliative care.

The concept of palliative care has been defined by several authors. World Health Organization defined palliative care as an approach that improves the quality of life of patients and their families facing problems associated with life-threatening illness through the relief of suffering by means of early identification, impeccable assessment and treatment of pain and other problems like physical, psychological and spiritual [2]. [3] defined palliative care as the care that is primarily directed at providing relief to a terminally ill person through symptom management and pain management. Similarly [4] explained that palliative care is alleviating symptoms, whether or not there is hope of a cure. The above definitions imply that palliative care is improving the functionality of the terminally ill.

[3] argued that people near the end of life do not only want to live life as fully as they can, they also want to be respected by healthcare providers who will in turn assist them in maintaining their dignity and independence while relieving symptoms and ensuring their comfort. Thus, nursing strategies and interventions must be geared towards managing individual's symptoms, and reducing the burden of pain. It therefore becomes paramount for nurses to possess adequate knowledge, the right attitudes and interpersonal competence to provide comfort and maintain the highest possible QoL. Knowledge of palliative is rudimentary to nursing care. Similarly, the attitude of nurses towards death and dying patients may influence the care nurses are able to provide. [3] asserted that not all nurses are comfortable with caring for the dying. Ideal attitude to palliative care is described as flexibility in interpersonal relations, desire for open communication about critical issues, and psychological mindedness in relation to patients and families of dying patients [4].

Palliative care was introduced into Nigeria in 1993 by Fatunmbi and Merriman [5]. In 2008, the Nigerian Federal Ministry of Health not only included elements of palliative care into the National Cancer Control Plan (2008-2013) as well as the National Guidelines for HIV and AIDS treatment and care in adolescents and adults [6], they also established palliative care units in 15 tertiary and secondary health institutions in Nigeria. Despite the presence of palliative care in Nigeria since a decade ago, it is observed that Nigeria is lagging behind in palliative care provision. It is pertinent to ask some basic questions. Is this situation related to the way palliative nursing is practiced in Nigeria? 
Practice of palliative care refers to the quality of end-of-life care provided to patients. The core of nursing intervention in this regard should focus on communication, pain and symptoms relief, knowledge of available resources, and fostering involvement in and control of decision making by the patient as long as possible. Other questions are, are practicing nurses in Nigeria knowledgeable about palliative care, what is their attitude towards it, and how exactly do they practice it? The premise is that based on the nurses' position within the healthcare system, they ought to play a significant role in palliative and end-of-life care. In search of answers to the above questions, this study was justified.

There are several factors that influence a successful practice of palliative care. These include healthcare professionals' knowledge, attitude, beliefs, and previous experiences. [7] asserted that these factors may influence the health professionals' behaviour during evaluation and treatment of patients. According to [8] nurses are a crucial component of palliative care delivery teams, developing plans of care, providing leadership for staff and guidance or support for patients and families Thus, to achieve a successful delivery of palliative care, nurses must not only possess the knowledge and skills to provide effective end-of-life care, but must also have the right attitudes and interpersonal competence to provide compassionate care [4].

Fourteen empirical studies were reviewed in this study.

Majority of the studies found favourable positive attitude towards palliative care among nurses [2] [3] [9] [10]. At the time of reporting this study, two studies [4] [11] found poor practice of palliative care and no known published studies examined the relationship between practice of palliative care among nurses and the type of hospital facility in which they work in. The researcher hopes that a study of this nature will fill this identified gap.

[4] found inadequate practice of palliative care which was inconsistent with [11]. Few studies have examined the association between practice of palliative care and demographic characteristics such as marital status, type of ward, level of education, and job experience. The researcher believes that the identified gap in practice underscores a need for an empirical investigation to assess the knowledge, attitude and practice of palliative care among nurses from selected hospitals in eastern part of Nigeria.

\subsection{Scope of the Study}

This study is expected to unravel the knowledge, attitude, practice of palliative care and the associations between knowledge of palliative care among nurses and their educational level, years of experience, type of ward, and type of hospital facility (public and private).

\subsection{Objective of the Study}

To identify the extent to the variables; knowledge and attitude of practicing nurses in eastern part of Nigeria influence their practice of palliative care. 


\subsection{Research Questions}

- Are respondents knowledgeable about palliative care?

- What is the attitude of these nurses to palliative care?

- To what extent do these nurses practice palliative care?

- To what extent do knowledge and attitude of these nurses influence their practice of palliative care?

\subsection{Hypothesis}

- There is no significant relationship between nurses' educational level and their knowledge of palliative care.

- There is no significant relationship between nurses' years of experience and their attitude to palliative care.

\section{Research Methodology}

The research design adopted for this study was descriptive cross sectional design. The study was set in eastern part of Nigeria. The population of the study is all registered, licensed and practicing nurses working in public and private hospitals where palliative care is supposedly well established. A sample size of 317 was determined for use in the study. The sample size was calculated using Taro Yamane formula (1967) $\left[\frac{N}{1+N e^{2}}\right]$. Where $N=\operatorname{target}$ population (989), $e=$ tolerable error margin (0.05). The minimum calculated sample size was 285 . To adjust the minimum sample size for potential attrition or fallout or non-response, a non-response adjustment formula for cross-sectional surveys was applied. Where Final sample size $=\frac{\text { Minimum sample size }}{1-\text { expected at trition of } 10 \%}$ [12], a final sample size of 317 was calculated. Participants who were willing to partake in the study and signed the informed consent form the population. Proportionate sampling technique was used to ensure good representation of nurses.

Three commercial instruments that measured knowledge, attitude, and practice of palliative care that were modified (without changing the content) were used to collect data. 1) Palliative Care Quiz for Nursing Questionnaire (PCQN) developed by [13] was used to assess nurses knowledge of palliative care, 2) Frommelt's Attitude toward Care Of the Dying Scale (FATCODS) developed by [14] was used to measure attitude while 3) Palliative Care Practice Scale (PCPS) developed by [15] was used to evaluate the clinical practice of palliative care. The instrument when pooled together has a total of 61 items, split into 4 sections (A D). The instruments were administered once.

Face and content validity were ascertained. The content validity index of scale for the questionnaire was found to be 0.922 . Reliability of the instrument was done using a split-half method. Alpha statistics yielded a coefficient of 0.857 . Level of significance was set at $P<0.05$. All statistical analysis was done with the aid of Statistical Package for Social Sciences (SPSS) version 20.0. Four trained 
research assistants collected data. A total of 317 copies of the questionnaire were administered, out of which 314 was returned (return rate 99\%). 25 were disqualified due to incomplete demographic data. 289 was found fit for data analysis (response rate 91.2\%). The selection criteria for participant include; willingness to participate in the study, has a current valid license endorsed by the Nursing and Midwifery Council of Nigeria, and must have nursed individuals with terminal disease conditions

\subsection{Ethical Clearance}

Due ethical clearance was obtained.

\subsection{Findings}

\section{Demographic profile of respondents}

The population was 989. Taro Yamane formula was used to determine the sample size which is 285 . To account for potential attrition, a non-response adjustment formula for cross-sectional survey was applied, thus, a final sample size of 317 was established.

Table 1 showed that the mean age of the respondents was 34.27 (8.58) years. Majority (43.6\%) of the respondents were aged 30 - 39 years. Most $(92.7 \%)$ of the respondents were females. Majority (40.1\%) of the respondents had RN/RM as their highest educational qualification. $87.9 \%$ of the respondents served in public hospitals. Majority of the respondents had $4-7$ years of clinical experience.

\section{Knowledge of palliative care}

Items 8 - 21 were analyzed to answer research question 1 . Table 2 summarized responses to Knowledge of palliative care among nurses.

Generally, majority (73.7\%) of the respondents had adequate knowledge of palliative care (mean $2.64(1.06)$ ). Meanwhile, the respondents had inadequate knowledge on palliative care being appropriate in situations of deteriorating condition, palliative care not requiring emotional detachment, drugs that can cause respiratory depression not being appropriate for dyspnoa, the philosophy of palliative care being compatible with aggressive treatment, the use of placebos not appropriate, and the risk of burnout (mean $<2.5$ ). The respondents were most knowledgeable on palliative care being provided for individuals who cannot benefit from curative therapy (mean $3.2(0.96)$ ). They were least knowledgeable on palliative care being appropriate care to individuals with deteriorating condition (mean 2.05 (0.98)).

\section{Attitude to palliative care}

Items 22 - 45 were analyzed to answer research question 2. Table 3 summarized responses on attitude to palliative care among nurses.

Overall, majority (77.5\%) of the respondents had positive attitude towards palliative care (Mean 2.81 (1.14)). Meanwhile, the respondents had felt that giving care to a dying patient is not a worthwhile learning experience, nursing care for patients' family should not continue throughout the period of grief, scary to 
Table 1. Demographic characteristics of respondents $(n=289)$.

\begin{tabular}{|c|c|c|c|c|c|}
\hline No. & Category & Detail & Mean (SD) & $F$ & $\%$ \\
\hline 1 & Mean age (in years) & & $34.27(8.58)$ & & \\
\hline \multirow[t]{5}{*}{2} & Age group (in years) & $20-29$ & & 86 & 29.8 \\
\hline & & $30-39$ & & 126 & 43.6 \\
\hline & & $40-49$ & & 57 & 19.7 \\
\hline & & $50-59$ & & 19 & 6.6 \\
\hline & & $60-69$ & & 1 & 0.3 \\
\hline \multirow[t]{2}{*}{3} & Gender & Female & & 268 & 92.7 \\
\hline & & Male & & 21 & 7.3 \\
\hline \multirow[t]{4}{*}{4} & Educational & $\mathrm{RN}$ & & 57 & 19.7 \\
\hline & Qualification & $\mathrm{RN} / \mathrm{RM}$ & & 116 & 40.1 \\
\hline & & B. NSc & & 108 & 37.4 \\
\hline & & M. NSc & & 8 & 2.8 \\
\hline \multirow[t]{2}{*}{5} & Type of hospital & Public & & 254 & 87.9 \\
\hline & & Private & & 35 & 12.1 \\
\hline \multirow[t]{4}{*}{6} & Years of & $0-3$ & & 90 & 31.1 \\
\hline & clinical experience & $4-7$ & & 96 & 33.2 \\
\hline & & $8-11$ & & 62 & 21.5 \\
\hline & & $12-15$ & & 41 & 14.2 \\
\hline 7 & Religion & Christianity & & 289 & 100 \\
\hline
\end{tabular}

Table 2. Knowledge of palliative care among nurses $(n=289)$.

\begin{tabular}{|c|c|c|c|c|c|c|c|c|c|}
\hline No. & Question & $\%$ & $\begin{array}{c}\mathrm{SA} \\
\mathrm{F}\end{array}$ & $\begin{array}{c}\text { A } \\
\mathrm{f}\end{array}$ & $\begin{array}{l}\mathrm{D} \\
\mathrm{F}\end{array}$ & $\begin{array}{c}\text { SD } \\
\mathrm{f}\end{array}$ & Mean & SD & Interpret \\
\hline 8 & Palliative care is only provided to patients who have no curative treatment? & & 142 & 91 & 29 & 27 & 3.20 & 0.96 & Adequate \\
\hline 9 & Palliative care is only appropriate in situations of deterioration in conditions. & & 44 & 15 & 142 & 88 & 2.05 & 0.98 & Inadequate \\
\hline 10 & $\begin{array}{l}\text { Method of Pain management in Palliative care is not determined } \\
\text { by severity of pain. }\end{array}$ & & 35 & 61 & 148 & 45 & 2.70 & 0.87 & Adequate \\
\hline 11 & Adjuvant therapies are important in managing pain. & & 112 & 61 & 67 & 49 & 2.81 & 1.12 & Adequate \\
\hline 12 & $\begin{array}{l}\text { Drug addiction is a major problem when morphine is } \\
\text { used on a long-term basis. }\end{array}$ & & 131 & 44 & 54 & 60 & 2.85 & 1.20 & Adequate \\
\hline 13 & The provision of palliative care requires emotional detachment. & & 90 & 39 & 72 & 88 & 2.45 & 1.21 & Inadequate \\
\hline${ }^{\dagger} 14$ & $\begin{array}{l}\text { During the terminal stages of an illness, drugs cause respiratory } \\
\text { depression is appropriate for severe dyspnoea. }\end{array}$ & & 72 & 70 & 102 & 45 & 2.41 & 1.02 & Inadequate \\
\hline 15 & The philosophy of palliative care is compatible with aggressive treatment. & & 67 & 57 & 96 & 69 & 2.42 & 1.09 & Inadequate \\
\hline 16 & The use of placebos is appropriate in the treatment of some types of pain. & & 70 & 56 & 125 & 38 & 2.45 & 0.99 & Inadequate \\
\hline 17 & $\begin{array}{l}\text { Morphine instead of Pethidine is the standard used to compare } \\
\text { the analgesic effect of other analgesics. }\end{array}$ & & 55 & 67 & 90 & 77 & 2.65 & 1.06 & Adequate \\
\hline 18 & The accumulation of losses renders burnout Inevitable. & & 51 & 58 & 114 & 66 & 2.32 & 1.01 & Inadequate \\
\hline 19 & Manifestations of chronic pain are different from those of acute pain. & & 118 & 51 & 75 & 45 & 2.83 & 1.12 & Adequate \\
\hline 20 & Terminally ill patients have the right to choose "Do not resuscitate" (DNR). & & 122 & 111 & 13 & 43 & 3.07 & 1.02 & Adequate \\
\hline \multirow[t]{4}{*}{21} & $\begin{array}{l}\text { It is not very crucial for family members to remain at bedside until } \\
\text { death occurs. }\end{array}$ & & 114 & 65 & 35 & 75 & 2.75 & 1.22 & Adequate \\
\hline & Grand Mean & & & & & & 2.64 & 1.06 & Adequate \\
\hline & Adequate Knowledge of palliative care & 73.7 & & & & & & & \\
\hline & Inadequate Knowledge of palliative care & 26.3 & & & & & & & \\
\hline
\end{tabular}

Decision rule: Mean $<2.5$ = inadequate; $\geq 2.5=$ adequate knowledge. ${ }^{\dagger}$ Items were reverse scored. 
Table 3. Attitude towards palliative care $(n=289)$.

\begin{tabular}{|c|c|c|c|c|c|c|c|c|c|}
\hline Item & Question & $\%$ & $\begin{array}{c}\text { SA } \\
\mathrm{f}\end{array}$ & $\begin{array}{l}\mathrm{A} \\
\mathrm{F}\end{array}$ & $\begin{array}{l}\mathrm{D} \\
\mathrm{F}\end{array}$ & $\begin{array}{c}\text { SD } \\
\mathrm{f}\end{array}$ & Mean & SD & Interpret \\
\hline 22 & $\begin{array}{l}\text { Palliative care is given only } \\
\text { for dying patient. }\end{array}$ & & 94 & 92 & 54 & 49 & 2.79 & 1.07 & Positive \\
\hline${ }^{\dagger} 23$ & $\begin{array}{l}\text { As a patient nears death; } \\
\text { the nurse withdraw. }\end{array}$ & & 51 & 42 & 135 & 61 & 2.71 & 0.99 & Positive \\
\hline${ }^{\dagger} 24$ & $\begin{array}{l}\text { Giving nursing care to the } \\
\text { chronically sick patient is } \\
\text { not a worthwhile. }\end{array}$ & & 88 & 74 & 57 & 70 & 2.37 & 1.15 & Negative \\
\hline${ }^{\dagger} 25$ & $\begin{array}{l}\text { It is not beneficial for the } \\
\text { chronically sick person to } \\
\text { verbalize his/her feelings. }\end{array}$ & & 34 & 59 & 32 & 164 & 3.12 & 1.10 & Positive \\
\hline${ }^{\dagger} 26$ & $\begin{array}{l}\text { Family members who stay close } \\
\text { to a dying person often interfere } \\
\text { with job. }\end{array}$ & & 13 & 77 & 64 & 135 & 3.11 & 0.95 & Positive \\
\hline${ }^{\dagger} 27$ & $\begin{array}{l}\text { The lengths of time required } \\
\text { frustrate me. }\end{array}$ & & 71 & 63 & 73 & 82 & 2.57 & 1.14 & Positive \\
\hline${ }^{\dagger} 28$ & $\begin{array}{l}\text { Families should not be concerned } \\
\text { about helping their dying make } \\
\text { the best of life. }\end{array}$ & & 45 & 10 & 83 & 151 & 3.17 & 1.07 & Positive \\
\hline${ }^{\dagger} 29$ & $\begin{array}{l}\text { Family should not maintain as } \\
\text { normal an environment as } \\
\text { possible for their dying. }\end{array}$ & & 32 & 38 & 38 & 181 & 3.27 & 1.06 & Positive \\
\hline${ }^{\dagger} 30$ & $\begin{array}{l}\text { The nurse should not be the one } \\
\text { to talk about death with the } \\
\text { dying person. }\end{array}$ & & 46 & 46 & 45 & 152 & 3.04 & 1.15 & Positive \\
\hline${ }^{\dagger} 31$ & $\begin{array}{l}\text { The family should not be involved } \\
\text { in the physical care of the dying } \\
\text { person. }\end{array}$ & & 56 & 58 & 117 & 58 & 3.38 & 1.59 & Positive \\
\hline${ }^{\dagger} 32$ & $\begin{array}{l}\text { It is difficult to form a close } \\
\text { relationship with the family of } \\
\text { a dying member. }\end{array}$ & & 62 & 24 & 99 & 104 & 2.84 & 1.13 & Positive \\
\hline${ }^{\dagger} 33$ & $\begin{array}{l}\ldots \text { no times when death is } \\
\text { welcomed by the dying }\end{array}$ & & 41 & 117 & 43 & 88 & 2.61 & 1.06 & Positive \\
\hline${ }^{\dagger} 34$ & $\begin{array}{l}\text { Nursing care for the patient's } \\
\text { family should not continue } \\
\text { throughout the period of grief. }\end{array}$ & & 88 & 103 & 69 & 29 & 2.13 & 0.96 & Negative \\
\hline${ }^{\dagger} 35$ & $\begin{array}{l}\text { The dying person and his/her } \\
\text { family should not be the in-charge } \\
\text { decision makers. }\end{array}$ & & 10 & 56 & 110 & 113 & 3.12 & 0.84 & Positive \\
\hline 36 & $\begin{array}{l}\text { Addiction to pain relieving } \\
\text { medication should not be a } \\
\text { nursing concern. }\end{array}$ & & 71 & 111 & 83 & 24 & 3.02 & 2.31 & Positive \\
\hline${ }^{\dagger} 37$ & $\begin{array}{l}\text { Nursing care should not extend } \\
\text { to the family of the dying person. }\end{array}$ & & 58 & 54 & 74 & 103 & 2.76 & 1.13 & Positive \\
\hline${ }^{\dagger} 38$ & $\begin{array}{l}\text { When a patient asks, "Nurse am I } \\
\text { dying?" I think it is best to change } \\
\text { the Subject ... }\end{array}$ & & 35 & 37 & 119 & 98 & 2.96 & 0.97 & Positive \\
\hline
\end{tabular}




\section{Continued}

\begin{tabular}{|c|c|c|c|c|c|c|c|c|c|}
\hline$\dagger 39$ & $\begin{array}{l}\text { I am afraid to become friends with } \\
\text { chronically sick and dying patients. }\end{array}$ & & 86 & 87 & 46 & 70 & 2.34 & 1.14 & Negative \\
\hline${ }^{\dagger} 40$ & $\begin{array}{l}\text { I would be uncomfortable if } \\
\text { I ... found him/her crying. }\end{array}$ & & 50 & 86 & 97 & 56 & 2.59 & 1.07 & Positive \\
\hline${ }^{\dagger} 41$ & $\begin{array}{l}\text { I would be uncomfortable talking } \\
\text { about impending death with the } \\
\text { dying Person. }\end{array}$ & & 98 & 67 & 70 & 54 & 2.31 & 1.19 & Negative \\
\hline${ }^{\dagger} 42$ & $\begin{array}{l}\text { It is not possible for nurses to } \\
\text { help patients prepare for death. }\end{array}$ & & 44 & 77 & 74 & 94 & 2.79 & 1.13 & Positive \\
\hline${ }^{\dagger} 43$ & $\begin{array}{l}\text { Death is the worst thing that } \\
\text { can happen ... }\end{array}$ & & 40 & 37 & 94 & 118 & 3.00 & 1.04 & Positive \\
\hline${ }^{\dagger} 44$ & $\begin{array}{l}\text { I would feel like running away } \\
\text { when the person actually died. }\end{array}$ & & 94 & 52 & 58 & 85 & 2.46 & 1.22 & Negative \\
\hline${ }^{\dagger} 45$ & $\begin{array}{l}\text { I would not want to care for } \\
\text { a dying person. }\end{array}$ & & 19 & 94 & 33 & 143 & 3.03 & 1.04 & Positive \\
\hline & Grand mean & & & & & & 2.81 & 1.14 & Positive \\
\hline & Positive attitude & 77.5 & & & & & & & \\
\hline & Negative attitude & 22.5 & & & & & & & \\
\hline
\end{tabular}

Decision rule: Mean $<2.5=$ Negative; $\geq 2.5=$ Positive. ${ }^{\dagger}$ Items were reverse scored.

become friends with the chronically sick, uncomfortable talking about death and dying, and would feel like running away when a patient died (mean $<2.5)$. The respondents had the most positive attitude on patients' family being involved in the care of the patient (mean 3.38 (1.59)). They had the most negative attitude on nursing care for patients' family continuing throughout the period of grief (mean $2.13(0.96)$ ).

\section{The practice of palliative care}

Items 46 - 54 were analyzed to answer research question 3. Table 4 summarized responses on practice of palliative care among nurses.

On the whole, about half (52.7\%) of the respondents had satisfactory practice of palliative care. Nonetheless, the respondents had unsatisfactory practice of palliative care on informing patients about their diagnosis, cultural assessment, and addressing psychological aspect of health and dying ( $\mathrm{f}<50 \%$ ). The respondents had the most satisfactory practice in communicating with the family of the terminally ill patient (69.6\%). They had the most unsatisfactory practice in assessing patients' level of pain (37.4\%). More than half (62.6\%) of the respondents did not use any objective scale or instrument for assessing the pain level of patients on palliative care.

Hypothesis 1: There is no significant relationship between nurses' educational level and their knowledge of palliative care.

Table 5 summarized test of hypothesis 1 . 
Table 4. Practice of palliative care among nurses $(n=289)$.

\begin{tabular}{|c|c|c|c|c|c|}
\hline No. & Question & $\%$ & $\begin{array}{c}\text { Correct } \\
\mathrm{f}(\%)\end{array}$ & $\begin{array}{c}\text { Incorrect } \\
f(\%)\end{array}$ & Interpretation \\
\hline 46 & Initiation of Palliative care & & $156(54.0)$ & $133(46.0)$ & Satisfactory \\
\hline 47 & $\begin{array}{l}\text { Informing terminally ill patient } \\
\text { about their diagnosis }\end{array}$ & & $133(46.0)$ & $156(54.0)$ & Not satisfactory \\
\hline 48 & $\begin{array}{l}\text { Factors to consider when dealing } \\
\text { with terminally ill }\end{array}$ & & $191(66.1)$ & $98(33.9)$ & Satisfactory \\
\hline 49 & Addressing the spiritual aspect & & $174(60.2)$ & $115(39.8)$ & Satisfactory \\
\hline 50 & Cultural assessment in patient care & & $122(42.2)$ & $167(57.8)$ & Not satisfactory \\
\hline 51 & Addressing psychological aspect & & $123(42.6)$ & $166(57.4)$ & Not satisfactory \\
\hline 52 & Palliative care decision making? & & $165(57.1)$ & $124(42.9)$ & Satisfactory \\
\hline 53 & $\begin{array}{l}\text { Communicating with the family of } \\
\text { terminally ill patient }\end{array}$ & & $201(69.6)$ & $88(30.4)$ & Satisfactory \\
\hline \multirow[t]{3}{*}{54} & Assessing patient's level of pain & & $108(37.4)$ & $181(62.6)$ & Not satisfactory \\
\hline & Satisfactory practice & 52.7 & & & \\
\hline & Unsatisfactory practice & 47.3 & & & \\
\hline
\end{tabular}

Decision rule: Mean $<50 \%=$ Not satisfactory; $\geq 50 \%=$ Satisfactory.

Table 5. Relationship between nurses' educational level and their knowledge of palliative care $(\mathrm{N}=289)$.

\begin{tabular}{|c|c|c|c|c|c|c|c|c|}
\hline \multirow{2}{*}{ Variables } & & \multicolumn{2}{|c|}{ Knowledge } & \multirow{2}{*}{ Df } & \multirow{2}{*}{$\begin{array}{c}\text { Chi square } \\
\text { Fisher } \\
\chi^{2}\end{array}$} & \multirow{2}{*}{$\begin{array}{c}\text { Cramer's } \\
\text { V } \\
\Phi\end{array}$} & \multirow{2}{*}{$\mathrm{p}$-value } & \multirow{2}{*}{ Sig. } \\
\hline & & $\begin{array}{c}\text { Inadequate } \\
\mathrm{F}\end{array}$ & $\begin{array}{c}\text { Adequate } \\
\text { F }\end{array}$ & & & & & \\
\hline Educational & $\mathrm{RN}$ & 25 & 32 & 3 & 13.892 & +0.219 & 0.003 & Sig. \\
\hline \multirow[t]{3}{*}{ Qualification } & $\mathrm{RN} / \mathrm{RM}$ & 21 & 95 & & & & & \\
\hline & B. NSc & 29 & 79 & & & & & \\
\hline & M. NSc & 1 & 7 & & & & & \\
\hline
\end{tabular}

Decision rule: $\mathrm{P}<0.05=$ significant, $>0.05=$ not significant.

On the whole there was significant association between nurses' educational level and their knowledge of palliative care $(P=0.003)$. The nature of this relationship is weak positive such that as educational qualification increases, there follows a mild increase in knowledge of palliative care $(\varphi=+0.219)$.

Hypothesis 2: There is no significant relationship between nurses' years of experience and their attitude to palliative care.

Table 6 summarized test of hypothesis 2 .

In general, there was significant association between nurses' years of experience and their attitude to palliative care $\left(P=0.000^{*}\right)$. The nature of this relationship is weak positive such that as years of clinical experience increases, there 
Table 6. Relationship between nurses' years of experience and their attitude to palliative care $(\mathrm{N}=289)$.

\begin{tabular}{|c|c|c|c|c|c|c|c|c|}
\hline \multirow{2}{*}{ Variables } & & \multicolumn{2}{|c|}{ Attitude } & \multirow{2}{*}{ df } & $\begin{array}{c}\text { Chi square } \\
\text { Fisher }\end{array}$ & $\begin{array}{c}\text { Cramer's } \\
\text { V }\end{array}$ & \multirow{2}{*}{ p-value } & \multirow{2}{*}{ Sig. } \\
\hline & & $\begin{array}{c}\text { Negative } \\
\text { F }\end{array}$ & $\begin{array}{c}\text { Positive } \\
\text { F }\end{array}$ & & $\chi^{2}$ & $\Phi$ & & \\
\hline Years of & $0-3$ & 27 & 63 & 3 & 36.633 & +0.356 & $0.000^{*}$ & Sig. \\
\hline Clinical & $4-7$ & 35 & 61 & & & & & \\
\hline \multirow[t]{2}{*}{ Experience } & $8-11$ & 3 & 59 & & & & & \\
\hline & $12-15$ & 0 & 41 & & & & & \\
\hline
\end{tabular}

Decision rule: $P<0.05=$ significant, $>0.05=$ not significant.

follows a mild increased positivity in attitude towards palliative care $(\varphi=$ $+0.356)$.

Hypothesis 3: There is no significant relationship between type of hospital facility nurses work in and their practice of palliative care.

Table 7 summarized test of hypothesis 3.

In all, there was no significant association between type of hospital facility nurses work in and their practice of palliative care $(P=0.343)$. The lack of any significant relationship between type of hospital facility nurses work in and their practice of palliative care was further substantiated by a Phi correlation $(\phi)$ value of +0.056 .

\section{Discussions}

\section{Knowledge of palliative care}

This study found that the knowledge of palliative care among nurses was generally good $(73.7 \%$, mean 2.64 (1.06)). This finding disagreed with [2] [16] studies. [2] found that $30.5 \%$ of the respondents had good knowledge of palliative care. The difference in finding could be due to the difference in the operational definition of good knowledge. While the present study operationalised good knowledge of palliative care as $\geq 50 \%$ with a mean $\geq 2.5$, [2] operationalized good knowledge of palliative care as $\geq 75 \%$. This discrepancy in criterion value would have influence conclusion decision within the separate studies. Additionally, this finding did not agree with [16] study. The author found that nurses have insufficient knowledge about the essence, philosophy, and principles of palliative care (mean 8.3(2.8), on a scale ranging from 0 to 15 . Similarly, the divergence in [16] this study, could be related to differences in instrument of data collection. [16] utilized a self-designed questionnaire, whereas a standard PCQN questionnaire that was modified was used in this study. It could be argued that the difference in item construction within domains and subdomains of measure may have introduced varaitions in sensitivity and specificity of the instruments.

Similar findings were recorded in studies by [17] and earlier study by [10]. [17] found that Paediatric nurses in Florida USA, had a good level of baseline 
Table 7. Relationship between type of hospital facility nurses work in and their practice of palliative care $(\mathrm{N}=289)$.

\begin{tabular}{|c|c|c|c|c|c|c|c|c|}
\hline \multirow{2}{*}{ Variables } & & \multicolumn{2}{|c|}{ Practice } & \multirow{2}{*}{$D f$} & $\begin{array}{l}\text { Chi square } \\
\text { Fisher }\end{array}$ & \multirow{2}{*}{ Phi $\Phi$} & \multirow{2}{*}{$\mathrm{p}$-value } & \multirow{2}{*}{ Sig. } \\
\hline & & $\begin{array}{c}\text { Not-Satisfactory } \\
\text { F }\end{array}$ & $\begin{array}{l}\text { Satisfactory } \\
\text { F }\end{array}$ & & $\chi^{2}$ & & & \\
\hline Type of & Public & 101 & 153 & 1 & 0.900 & +0.056 & 0.343 & Not sig. \\
\hline Hospital & Private & 11 & 24 & & & & & \\
\hline
\end{tabular}

Decision rule: $\mathrm{P}<0.05=$ significant, $>0.05=$ not significant

knowledge of palliative care (mean $3.12(0.31)$ ). The similarity in findings could be linked to the proximity in sample size utilized by [17] and the present study. Where the present study examined a sample size of 289, [17] assessed a sample size of 279. The present study and [10] utilized a multi-facility approach. This multi-facility approach may have reduced sampling error.

\section{Attitude to palliative care}

In this study $77.5 \%$ of the respondents had positive attitude towards palliative care (Mean 2.81 (1.14)). Similar findings were recorded in studies by [2] [4] [9]. [9] found that oncology and ICU nurses had positive attitude toward palliative care (3.18 \pm 0.37 out of 5). Both the present study and [9] utilized Frommelt Attitude toward Care of the Dying (FATCOD) questionnaire for assessing attitude of nurses towards palliative care. [2] study done in Addis-Ababa Ethiopia, found that $76 \%$ had positive attitude towards palliative care. Cross-sectional descriptive design was used in both studies. 58.9\% of the respondents in [4] study had positive attitude towards palliative care. [4] and the present study utilized self-report questionnaire method of data collection that allows respondents to give responses without fear of reproach, thereby reducing chances of Hawthorne effect [18].

In contrast, this finding was in conflict with [19] study in South-East Iran. These authors found that, nurse have negative to neutral attitudes toward palliative care ( $2.99 \pm 0.29$ out of 5$)$. The difference in findings could be related to the demography of nurses in the separate studies. While the present study sampled nurses irrespective of their clinical location, [19] samples were nurses working in oncology and intensive care. Thus, the findings of [19] study are limited and cannot be generalized for nurses in Iran.

\section{Practice of palliative care}

This study found that about half (52.7\%) of the respondents had satisfactory practice of palliative care. This finding was not in agreement with [2] who is in a study on assessment of knowledge, attitude and practice and associated factors towards palliative care among nurses working in Addis-Ababa Ethiopia, found that $76.2 \%$ of nurses had poor practice of palliative care. The difference in findings could be liked to differences in sampling technique used in the separate studies. [2] utilized multistage sampling method, whereas the present study uti- 
lized proportionate sampling technique. Multistage sampling tends to be less accurate than proportionate sampling but practicable when the population is large and widely dispersed as was the case in [2] who sampled out of about 10,000 nurses. On the other hand, proportionate sampling may result in insufficient numbers for making comparisons among strata and conclusions [18]. As obtainable in the present study, nurses serving in private hospitals made up $12.1 \%$ of the study sample. This could introduce some degree of bias to the results and conclusions of the study. This study supports [10] study on palliative care among nurses in Lebanon. Both the present study and [10] utilized a cross-section of nurses irrespective of the ward that these nurse work.

Relationship between nurses' educational level and their knowledge of palliative care

This study showed a significant weak positive association between nurses' educational level and their knowledge of palliative care $(P=0.003)$ with an effect size of $21.9 \%$. This means that this association will hold true in about one in every five of the respondents. This finding was not supported by [2] who found no significant association between educational level of nurses and their knowledge of palliative care. The difference in findings could be due to the proportion of degree and diploma holders in the sample used in the separate studies.

Relationship between nurses' years of experience and their attitude to palliative care

This study found significant weak positive association between nurses' years of experience and their attitude to palliative care $\left(P=0.000^{\star}\right)$ with an effect size of $35.6 \%$. This finding was supported by [19] who is in a study on nurses' attitudes toward palliative care in south-east Iran. The similarity in findings could be linked to the level of significance used in the separate studies. Both [19] and the present study utilized $5 \%$ level of significance to control for the risk of a Type 1 error [18].

In contrast, the finding of this study was not in agreement with [2] [4] that found that no significant relationship between attitude toward palliative care and nurses' years of experience at the $\mathrm{P}$ values of $(P>0.05)$ and $(P=0.27)$ respectively. The divergence in findings could be connected to differences in methods of data analysis used in the studies. [4] utilized t-test parametric statistical method, whereas the present study utilized chi square non-parametric statistical method. Parametric tests are more powerful than non-parametric tests, but non-parametric are used instead when a normal distribution cannot be assumed [18]. [2] utilized a class interval of 5 (i.e. $<5$ years, 5 - 10 years, 11 - 15 years, and $>20$ years), whereas the present study utilized a class interval of 4 (i.e. 0 - 3 years, 4 - 7 years, 8 - 11 years, and 12 - 15 years). Purists agree that class intervals used in the classification of ordinal data can affect the external conclusion of validity of test of hypothesis [18].

Relationship between type of hospital nurses work in and their practice of palliative care

This study found that there was no significant association between type of 
hospital facility nurses work in and their practice of palliative care $(P=0.343)$. Unfortunately, there is a dearth of studies in nursing journal on this relationship. No study examining the relationship between type of hospital nurses work and their practice of palliative care was found in US National Library of Medicine Pubmed and PubMedCentral databases. The premise for a need to examine this relationship is that good palliative care practices will abound in hospitals that have necessary human and material resources and infrastructure. This calls for more empirical studies.

\subsection{Limitations of the Study}

The weakness to the external conclusion validity of this study includes:

Unequal sample arms: the sampling technique (proportionate sampling allocation) used in the study generated a skewed non-equivalent distribution of respondents between respondents who work in public hospitals $(87.9 \%)$ and those who work in private hospitals $(12.1 \%)$. This non-equivalence in sample arms is a limitation to carrying out a fair comparison of practice and test of relationship between type of hospital nurses work in and their practice. Based on this limitation, caution should be applied if the findings of the present study were to be used for generalization purposes.

Method of data collection: another limitation of the study is the method of data collection. This study utilized self-report questionnaire method for data collection on practice of palliative care. Since practice of palliative care relates to the psychomotor domain of human behaviour, one important fact to consider is the accuracy of self-reports. Can the researcher be so sure that respondents act exactly the way they reported they do at all times, particularly if true responses would reveal embarrassing behavior. Based on the premise that humans all have the tendency to present ourselves positively, this may conflict with the truth, hence conclusion validity of a study [18]. Blinded (disguised) observation method of data collection should have been more appropriate. Observation methods are more versatile and can be used to gather data on nurses' verbal and non-verbal communication or behavior and skill attainment. Based on the identified limitation, caution should be applied if the findings of the present study were to be used for generalization purposes.

\subsection{Implication to the Nursing}

The findings of the present study suggest that these nurses have adequate knowledge and a favorable attitude to care for dying patients. However, mentorship and better education on palliative care practices is needed at the three levels of care in healthcare delivery system in Nigeria. Thus, appropriate curriculum for palliative care education must be developed and implemented to improve theoretical knowledge and practice of palliative care. In addition, more empirical studies are needed to examine the relationship between types of hospital facility nurses work in and their practice of palliative care. An understanding of this re- 
lationship will ensure that hospitals have the necessary infrastructure for appropriate practice of palliative care.

\section{Conclusion}

This study concluded that the respondents had a satisfactory (borderline) practice of palliative with adequate knowledge and a favorable attitude towards individuals in need of palliative care.

\section{Conflicts of Interest}

The authors declare no conflicts of interest regarding the publication of this paper.

\section{References}

[1] World Health Organization (WHO) (2017) Life Expectancy: Global Health Observatory Data.

[2] Kassa, H., Murugan, R., Zewdu, F., Hailu, M. and Woldeyohannes, D. (2014) Assessment of Knowledge, Attitude and Practice and Associated Factors towards Palliative Care among Nurses Working in Selected Hospitals, Addis Ababa, Ethiopia. BMC Palliative Care, 13, 6. https://doi.org/10.1186/1472-684X-13-6

[3] Karkada, S., Nayak, B. and Malath, I. (2011) Awareness of Palliative Care among Diploma Nursing Students. Indian Journal of Palliaive Care, 17, 20-23. https://doi.org/10.4103/0973-1075.78445

[4] Ali, W. and Ayoub, N. (2010) Nurses' Attitudes toward Caring for Dying Patient in Mansoura University Hospitals. Journal of Medicine and Biomedical Sciences, 3, 16-23.

[5] Oyebola, F. (2017) Palliative Care Trends and Challenges in Nigeria: The Journey So Far. Journal of Emergency and Internal Medicine, 1, 17. https://doi.org/10.15406/hpmij.2017.01.00002

[6] Shambe, I. (2014) Palliative Care in Nigeria: Challenges and Prospects. Jos Journal of Medicine, 8, 53-54.

[7] Prem, V., Karvannan, H., Kumar, S.P., Karthikbabu, S., Syed, N., Sisodia, V., et al. (2012) Study of Nurses' Knowledge about Palliative Care: A Quantitative Cross Sectional Survey. Indian Journal of Palliative Care, 18, 122-127. https://doi.org/10.4103/0973-1075.100832

[8] Pope, A. (2013) Palliative Care Knowledge among Bachelors of Science Nursing Students. Dissertations, Theses and Capstone Projects, Paper 596, Kennesaw State University, Kennesaw.

[9] Iranmanesh, S., Razban, F., Ghazanfari, Z. and Nejad, A. (2014) Nurses' Professional Autonomy and Attitudes toward Caring for Dying Patients in South-East Iran. Inernaional Journal of Palliative Nursing, 20, 294-300. https://doi.org/10.12968/ijpn.2014.20.6.294

[10] Abu-saad, H. and Dimassi, H. (2007) Palliative Care in Lebanon: Knowledge, Attitudes and Practices of Physicians and Nurses. The Lebanese Medical Journal, 55, 121-128.

[11] Brazil, K., Kaasalainen, S., McAiney, C., Brink, P. and Kelly, M. (2012) Knowledge and Perceived Competence among Nurses Caring for the Dying in Long-Term Care Homes. International Journal of Palliative Nursing, 18, 77. 
https://doi.org/10.12968/ijpn.2012.18.2.77

[12] Rota, B. and Laitila, T. (2015) Comparison of Some Weighting Methods of Nonresponse Adjustment. Lithuanian Journal of Statistics, 54, 69-83. https://doi.org/10.15388/LJS.2015.13882

[13] Ross, M., McDonald, B. and Mcguiness, J. (1996) The Palliative Care Quiz for Nursing (PCQN). Journal of Advanced Nursing, 23, 126-127. https://doi.org/10.1111/j.1365-2648.1996.tb03106.x

[14] Frommelt, K.H. (1991) Frommelt's Attitude toward Care of the Dying Scale (FATCODS). University of Buffalo, New York.

[15] Nakazawa, Y., Miyashita, M., Morita, T., Umeda, M., Oyagi, Y. and Ogasawara, T. (2010) The Palliative Care Self-Reported Practices Scale. Journal of Palliative Medicine, 13, 427-437. https://doi.org/10.1089/jpm.2009.0289

[16] Al Qadire, M. (2014) Nurses Knowledge about Palliative Care: A Cross-Sectional Survey. Journal of Hospice \& Palliative Nursing, 16, 23-30. https://doi.org/10.1097/NJH.0000000000000017

[17] Knapp, et al. (2011) Pediatric Nurses' Attitude towards Hospice and Pediatric Palliative Care. Pediatric Nursing Journal, 37, 77.

[18] Polit, D. and Beck, C. (2012) Nursing Research: Generating and Assessing Evidence for Nursing Practice. 9th Edition, Wolters Kluwer, Philadelphia.

[19] Razban, F., Iranmanesh, S. and Rafiei, H. (2013) Nurses' Attitudes toward Palliative Care in South-East Iran. International Journal of Palliative Nursing, 19, 403.

https://doi.org/10.12968/ijpn.2013.19.8.403 


\section{Questionnaire}

RESEARCH TOPIC: THE PRACTICE OF PALLIATIVE CARE AMONGST NURSES IN SELECTED HOSPITALS IN EASTERN NIGERIA

Instruction: Please write or tick your honest response to the questionnaire items.

Section A: Socio-demographic Profile

1) How old were you on your last birthday? (please write)

2) Which age range below does your age fall within?
a) 18 - 27 years
b) 28 - 37 years
c) $38-47$ years
d) 48 - 57 years
e) $58-67$ years
f) 68 - 77 years
3) What is your gender?
g) Female
h) Male

4) What is your highest educational qualification in Nursing Sciences?

i) $\mathrm{RN}$

j) $R N / R M$

k) B.NSc

l) M.NSc

m) Ph.D

5) What type of hospital facility do you work in?

n) Public (Government owned)

o) Private (Individual owned)

6) Years of clinical nursing experience?

p) 0 - 3 years

q) 4 - 7 years

r) 8 - 11 years

s) $12-15$ years

7) What is your religion?

t) Traditionalism

u) Christianity

v) Islam

Section B: Knowledge of Palliative Care

\begin{tabular}{|c|c|c|c|c|c|}
\hline Item & Question & $\begin{array}{c}\text { Strongly } \\
\text { Agree }\end{array}$ & Agree & Disagree & $\begin{array}{c}\text { Strong } \\
\text { Disagree }\end{array}$ \\
\hline 8 & $\begin{array}{l}\text { Palliative care is only provided to patients } \\
\text { who have no curative treatment } \\
\text { available for them? }\end{array}$ & & & & \\
\hline
\end{tabular}




\section{Continued}

Palliative care is only appropriate in

9 situations of a downhill trajectory or deterioration in conditions.

Method of Pain management in Palliative

10 care is not determined by the severity of pain in disease.

Adjuvant therapies are important in

11 managing pain as pain is not only relieved by drugs

Drug addiction is a major problem when

12 morphine is used on a long-term basis for the management of pain.

13

The provision of palliative care requires emotional detachment.

During the terminal stages of an illness, drugs that can cause respiratory depression

14 are appropriate for the treatment of severe dyspnoea.

The philosophy of palliative care is compatible with that of aggressive treatment.

The use of placebos is appropriate in the treatment of some types of pain.

Morphine instead of Pethidine is the

17 standard used to compare the analgesic effect of other analgesics.

The accumulation of losses renders

18 burnout Inevitable for those who work in palliative care.

19

Manifestations of chronic pain are different from those of acute pain.

20

Terminally ill patients have the right to choose "Do not resuscitate" (DNR).

21

It is not very crucial for family members to remain at bedside until death occurs.

\section{Section C: Attitude towards Palliative Care}

\begin{tabular}{|c|c|c|c|c|c|}
\hline Item & Question & $\begin{array}{l}\text { Strongly } \\
\text { Agree }\end{array}$ & Agree & Disagree & $\begin{array}{c}\text { Strong } \\
\text { Disagree }\end{array}$ \\
\hline 22 & Palliative care is given only for dying patient. & & & & \\
\hline 23 & $\begin{array}{l}\text { As a patient nears death; the nurse } \\
\text { should withdraw from his/her involvement } \\
\text { with the patient. }\end{array}$ & & & & \\
\hline 24 & $\begin{array}{l}\text { Giving nursing care to the chronically } \\
\text { sick patient is not a worthwhile learning } \\
\text { experience. }\end{array}$ & & & & \\
\hline 25 & $\begin{array}{l}\text { It is not beneficial for the chronically sick } \\
\text { person to verbalize his/her feelings. }\end{array}$ & & & & \\
\hline
\end{tabular}




\section{Continued}

26
Family members who stay close to a dying person often interfere with a professionals job with the patient.

The length of time required to give nursing care to a dying person would frustrate me.

Families should not be concerned about helping their dying member make the best of his/her remaining life.

Family should not maintain as normal an environment as possible for their dying member.

The nurse should not be the one to talk about death with the dying person.

The family should not be involved in the physical care of the dying person.

It is difficult to form a close relationship with the family of a dying member.

There are no times when death is welcomed by the dying person.

Nursing care for the patient's family should not continue throughout the period of grief and bereavement.

The dying person and his/her family should not be the in-charge decision makers.

Addiction to pain relieving medication should not be a nursing concern.

Nursing care should not extend to the family of the dying person.

When a patient asks, "Nurse am I dying?" I think it is best to change the Subject to something cheerful.

I am afraid to become friends with chronically sick and dying patients.

I would be uncomfortable if I entered the room of a terminally ill person and found him/her crying.

I would be uncomfortable talking about impending death with the dying Person.

It is not possible for nurses to help patients prepare for death.

Death is the worst thing that can happen to a person.

I would feel like running away when the person actually died.

I would not want to be assigned to care for a dying person. 


\section{Section D: Practice of Palliative Care}

\begin{tabular}{|c|c|c|c|}
\hline Item & Question & Options & $\begin{array}{l}\text { Tick as many } \\
\text { responses that } \\
\text { are applicable }\end{array}$ \\
\hline 46 & $\begin{array}{l}\text { You Initiate palliative } \\
\text { care discussion: }\end{array}$ & $\begin{array}{c}\text { During diagnosis } \\
\text { When the disease progress } \\
\text { At the end of life }\end{array}$ & \\
\hline 47 & $\begin{array}{l}\text { Do you inform terminally ill } \\
\text { patient about their diagnosis? }\end{array}$ & $\begin{array}{c}\text { Yes } \\
\text { No } \\
\text { Depending on family's wish } \\
\text { Not applicable }\end{array}$ & \\
\hline 48 & $\begin{array}{l}\text { The most important factor that } \\
\text { you consider when dealing with } \\
\text { terminally ill patient: }\end{array}$ & $\begin{array}{c}\text { Spiritual } \\
\text { Medical situation } \\
\text { Cultural } \\
\text { Psychological }\end{array}$ & \\
\hline 49 & You address the spiritual issue by: & $\begin{array}{l}\text { Connect with spiritual counsellor } \\
\text { Listen with empathy } \\
\text { Impose your own view } \\
\text { Understand patient reaction }\end{array}$ & \\
\hline 50 & $\begin{array}{l}\text { Which of the following do you } \\
\text { include during Cultural assessment } \\
\text { in patient care: }\end{array}$ & $\begin{array}{c}\text { Truth telling and decision making } \\
\text { Preference regarding disclosure } \\
\text { of information } \\
\text { Dietary preference } \\
\text { Language, family communication } \\
\text { Perspective on death, } \\
\text { suffering and grieving }\end{array}$ & \\
\hline 51 & You address psychological aspect by: & $\begin{array}{c}\text { Emotional support } \\
\text { Counselling the patient } \\
\text { Hiding the truth }\end{array}$ & \\
\hline 52 & $\begin{array}{l}\text { Who do you involve as the most } \\
\text { important person during } \\
\text { palliative care decision making? }\end{array}$ & $\begin{array}{c}\text { Patient } \\
\text { Family } \\
\text { Me the Nurse } \\
\text { Other health professionals }\end{array}$ & \\
\hline 53 & $\begin{array}{l}\text { How you communicate with the } \\
\text { family of terminally ill patient } \\
\text { depends on: }\end{array}$ & $\begin{array}{l}\text { Family's ability to assimilate } \\
\text { Their involvement } \\
\text { in decision making } \\
\text { Your willingness to disclose } \\
\text { information }\end{array}$ & \\
\hline 54 & $\begin{array}{l}\text { You assess patient's level of } \\
\text { pain using? }\end{array}$ & $\begin{array}{l}\text { Visual analogue scale (VAS) } \\
\text { Numerical rating scale (NRS) } \\
\text { Categorical Pain Scale } \\
\text { No instrument }\end{array}$ & \\
\hline
\end{tabular}

